\title{
Protective effect of edaravone on adriamycin- induced cardiotoxicity in rats
}

\section{Ratlarda adriamisin kaynaklı kardiyotoksisite üzerine edaravonun koruyucu etkisi}

\author{
Hatice Aygüin ${ }^{1 *}$, Serdar Savaş Güill ${ }^{2}$
}

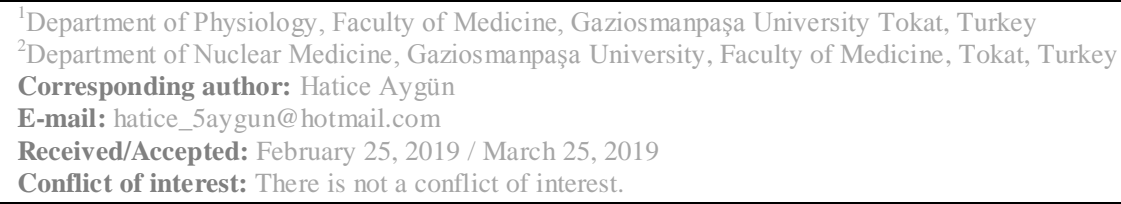

\section{SUMMARY}

Aim: Adriamycin (ADR) is an antineoplastic drug that is widely used in chemotherapy but its cardiotoxicity is the most important side effect that limits the clinical use of this drug. In this study, we investigated of edaravone (EDO), which is a potent antioxidant, ADR-induced cardiotoxicity model in rats by electrocardiographic (ECG), biochemical and scintigraphic methods.

Methods: Twenty-eight adult male Wistar-Albino rats were randomly separated into four groups; namely control $(\mathrm{CON})$; Adriamycin (ADR); substance control of edaravone (EDO), edaravone + adriamycin (EDO+ADR) groups. Cardiotoxicity in rats was induced by adriamycin injection (cumulative dose: $18 \mathrm{mg} / \mathrm{kg}$, intraperitoneal-i.p.-) at an interval of 24 hours $(\mathrm{h})$ on the $5^{\text {th }}, 6^{\text {th }}$ and $7^{\text {th }}$ days. Rats receiving edaravone treatment in the adriamycin group administration edaravone $(30 \mathrm{mg} / \mathrm{kg} /$ day, i.p. $)$ for 7 days and were injected with adriamycin $(18 \mathrm{mg} / \mathrm{kg}$, i.p. $)$ on $5^{\text {th }}, 6^{\text {th }}$ and $7^{\text {th }}$ days. On the $8^{\text {th }}$ day electrocardiography (ECG), biochemical and technetium- $99 \mathrm{~m}$ pyrophosphate $\left({ }^{99 \mathrm{~m}} \mathrm{Tc}-\mathrm{PYP}\right)$ scintigraphic parameters were assessed.

Results: ADR induction caused changes in the ECG pattern, decreased heartbeat, $\mathrm{P}$ wave and QRS complex duration, increased both ST-segment amplitude and QT interval duration $(\mathrm{p}<0,001)$, increase in the biochemical markers [blood urea nitrogen (BUN), creatine kinase (CK), cardiac troponin T (cTnT)], and elevated ${ }^{99 \mathrm{~m}}$ Tc-PYP uptake level (p < 0,001). EDO treatment prevented all the parameters of ADR-induced cardiotoxicity in rats, by significantly decreased all ADR-associated conduction abnormalities in ECG $(p<0.001)$, decreased ${ }^{99 \mathrm{~m}}$ Tc-PYP uptake $(\mathrm{p}<0.001)$ and serum BUN, CK and cTnT, (p < 0.001).

Conclusions: Our data demonstrate that EDO has cardioprotective effects on DOX-induced cardiotoxicity. At the same time, this study suggested that ${ }^{99 m}$ Tc-PYP may be using as a non-invasive method for the early diagnosis of ADRinduced cardiotoxicity.

Keywords: Adriamycin, cardiotoxicity, edaravone, ${ }^{99 \mathrm{~m}} \mathrm{Tc}-\mathrm{PYP}, \mathrm{ECG}$.

\section{ÖZET}

Amaç: Adriamisin (ADR), kemoterapide yaygın olarak kullanılan antineoplastik bir ilaçtır, ancak kardiyotoksisitesi, bu ilacın klinik kullanımını sınırlayan en önemli yan etkidir. Bu çalışmada, ratlarda adriamisin ile oluşturulan kardiyotoksisite modelinde güçlü bir antioksidan olan edaravonun (EDO) etkisini elektrokardiyografik (EKG), biyokimyasal ve sintigrafik yöntemlerle araştırdık.

Yöntem: Yirmi sekiz erişkin erkek Wistar-Albino rat rastgele dört gruba ayrıldı; kontrol (CON); Adriamisin (ADR); edaravon (EDO), edaravon + adriamisin (EDO + ADR). Ratlarda kardiyotoksisite, 5., 6. ve 7. günlerde 24 saatlik (h) aralıklarla ADR enjeksiyonu (kümülatif doz: $18 \mathrm{mg} / \mathrm{kg}$, intraperitoneal-i.p.-) ile indüklenmiştir. EDO + ADR grubu uygulamasında ratlara 7 gün boyunca EDO (30 mg / kg / gün, i.p.) uyguladi ve 5., 6. ve 7. günlerde ADR (18 mg / kg, i.p.) enjekte edildi. 8. günde elektrokardiyografi (EKG), biyokimyasal ve teknesyum-99m pirofosfat $\left({ }^{99 m} \mathrm{Tc}-\mathrm{PYP}\right)$ sintigrafik parametreleri değerlendirildi.

Bulgular: ADR indüksiyonu EKG paterninde değişikliklere neden oldu; kalp atışı, P dalgası ve QRS kompleks süresi azaldı, hem ST-segment genliğini hem de QT süresini arttırdı $(\mathrm{p}<0,001)$, ayrıca biyokimyasal belirteçlerde artış izlendi [kan üre azotu (BUN), kreatin kinaz (CK), kardiyak troponin T (cTnT)] ve yüksek 99mTc-PYP uptakei seviyesi (p < 
0,001). EDO tedavisi, ratlarda ADR'nin neden olduğu kardiyotoksisite parametrelerinin tümünü engelledi, EKG'deki tüm ADR'e bağlı anormallikler, ${ }^{99 \mathrm{~m}}$ Tc-PYP uptakei ve serum BUN, CK ve cTnT seviyeleri önemli ölçüde azaldı ( $\mathrm{p}$ $<0.001$ ).

Sonuç: Verilerimiz, EDO’nun ADR kaynaklı kardiyotoksisite üzerinde kardiyoprotektif etkilere sahip olduğunu göstermektedir. Aynı zamanda, bu çalışma ${ }^{99 m}$ Tc-PYP'nin ADR'nin neden olduğu kardiyotoksisitenin erken teşhisi için non-invaziv bir yöntem olarak kullanabileceğini düşündürmektedir.

Anahtar sözcükler: Adriamisin, kardiyotoksisite, edaravon, ${ }^{99 \mathrm{~m}}$ Tc-PYP, EKG.

\section{INTRODUCTION}

Adriamycin (ADR) or doxorubicin is most commonly used effective anti-neoplastic drug for the treatment of a wide range of cancers including both solid tumor, leukemia, breast cancer, and hematogenous cancers ${ }^{1,2}$. However, the clinical application of ADR is limited due to undesirable side effects including cardiotoxicity. ADRinduced cardiotoxicity could lead to irreversible degenerative congestive arrhythmia, cardiomyopathy, left ventricular dysfunction, heart failure, and cardiomyopathy ${ }^{3}$. In addition, ADR-induced cardiotoxicity is still not yet fully understood, but emerging data implicate the role of production of free radicals and subsequent oxidative stress ${ }^{4}$. ADR-induced oxidative stress has been shown to be inhibited by the treatment of antioxidants in many experimental animals models $^{5-9}$.

On the other hand, the ADR-induced cardiotoxicity has a poor prognosis for available treatment, and it is frequently fatal. Thus, the searches of the prevention of ADR-induced cardiotoxicity have been a subject of great interest and a hotspot in recent years. Recently, edaravone (EDO), a potent antioxidant and free radical scavenger, was clinically used to ALS treatment and reduce neuronal damage following ischemic stroke $^{10}$. Previous studies demonstrated that EDO has a cardioprotective agent by in the ischemic myocardium in rats and inhibiting the lipoxygenase pathway of arachidonic acid ${ }^{11,12}$.

In the present study, we aimed to further investigate the cardioprotective potential of edaravone against ADR-induced cardiotoxicity by electrocardiography (ECG), biochemical and technetium-99m pyrophosphate $\left({ }^{99 \mathrm{~m}} \mathrm{Tc}-\mathrm{PYP}\right)$ scintigraphic imaging.

\section{MATERIALS AND METHODS}

\section{Animal Tests and Experimental Design}

Male Wistar-Albino rats, weighing 220-250 g, were randomized to 4 groups, each group containing 7 animals. Animals were housed under standardized conditions (12-hour (h) light/ dark cycle, $23 \pm 3^{\circ} \mathrm{C}, 55-60 \%$ humidity). Food (standard, pellet feed) and water were available ad libitum. All procedures and experiments were approved by the Animal Ethics Committee of Gaziosmanpaşa University (2018-HADYEK-08) and performed in accordance with the guidelines of the National Institute of Health Guide for the Care and Use of Laboratory Animals.

\section{Experimental Procedures}

The experimental groups were as follows:

(1) Group 1 (CON): Animals received sterile physiologic saline (4 ml/kg i.p.) only and named as the control group.

(2) Group 2 (ADR): The cardiotoxicity was induced by a cumulative dose of $18 \mathrm{mg} / \mathrm{kg}$ adriamycin injection (i.p.) at an interval of $24 \mathrm{~h}$ on the last three days of the study $\left(5^{\text {th }}, 6^{\text {th }}\right.$ and $7^{\text {th }}$ days) only and named as the adriamycin group

(3) Group 3 (EDO): As edaravone substance control treatment, animals were given the only edaravone at a dose of $30 \mathrm{mg} / \mathrm{kg} / \mathrm{day}$, i.p., for 7 days of the experiment.

(3) Group 4 (ADR + EDO): In the edaravone treatment group, animals were treated with edaravone $(30 \mathrm{mg} / \mathrm{kg} / \mathrm{day}$, i.p.) for 7 days followed by adriamycin injection (cumulative dose: $18 \mathrm{mg} / \mathrm{kg}$, i.p.) on the $5^{\text {th }}, 6^{\text {th }}$ and $7^{\text {th }}$ days.

Electrocardiography $\quad$ (ECG), $\quad{ }^{99 \mathrm{~m}} \mathrm{Tc}-\mathrm{PYP}$ scintigraphy and biochemical parameters were assessed on the $8^{\text {th }}$ day of the study

\section{Drugs and Chemicals}

EDO was purchased from Sigma-Aldric. ADR was purchased from a local pharmacy. All drugs were dissolved in normal saline. The doses of EDO and ADR were determined in accordance with previous studies $5,6,11,12$. 


\section{Electrocardiography}

At the end of the experimental period, the animals were anesthetized i.p injection with ketamine (75 $\mathrm{mg} / \mathrm{kg}$, Pfizer, İstanbul, Turkey) plus xylazine (10 $\mathrm{mg} / \mathrm{kg}$, Bayer, İstanbul, Turkey). Anesthesia was assessed by pedal reflex. Three needle electrodes were placed under the skin of the rats in limb lead II position (depicted in Figure 1): the negative electrode was placed to the skin of the front paws and the positive electrode to the left hind legs paws. ECG recordings were taken 1 minute by computerized MP-150 multi-channel physiological analysis system (BioPac Systems Inc.; USA). Changes in ECG pattern (heartbeat (bpm) duration of the $\mathrm{P}$ wave, QRS complex, QT interval and amplitude of ST segment,) were assayed.

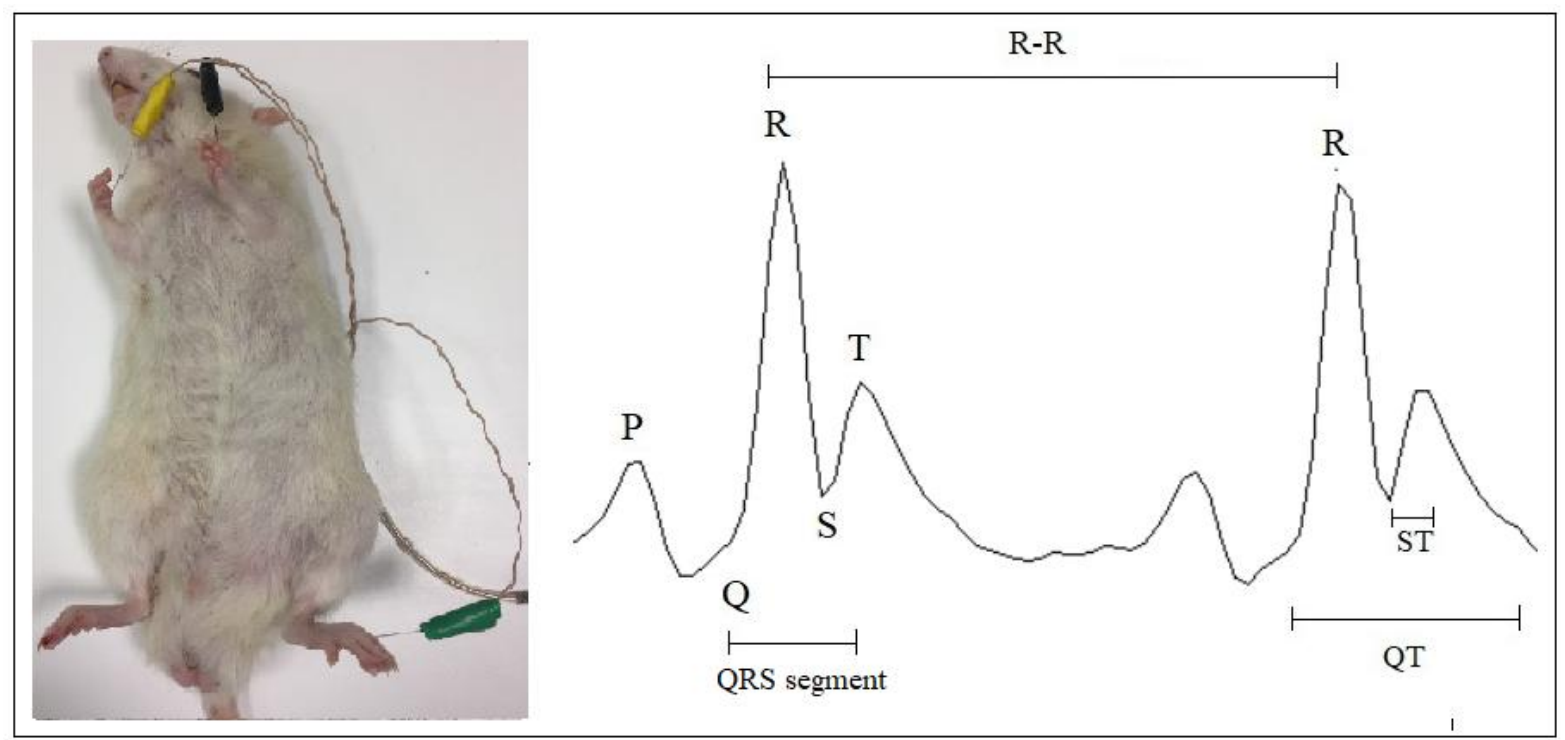

Figure 1. ECG recording of the a normal Wistar rats for the limb lead at position II. The negative needle electrode was placement to the skin of the front paws and the positive electrode to the left hind legs paws.

\section{Scintigraphic Images}

$37 \mathrm{Mbq}{ }^{99 \mathrm{~m}}$ Tc-PYP radiopharmaceutical was injected i.p. to anesthetized rats ${ }^{8,9}$. One hour after ${ }^{99 \mathrm{~m}}$ Tc-PYP radiopharmaceutical injection and after ECG recording, static imaging with a dual head gamma camera (E-CAM, Siemens, Germany) was performed in anterior and posterior positions with 2.55 zoom factor. The radionuclide uptake heart area was measured by drawing equal rectangular regions of interest (ROI) and ${ }^{99 \mathrm{~m}} \mathrm{Tc}-\mathrm{PYP}$ uptake was calculated by the semi-quantitative method to all study groups, (Figure 3).

\section{Biochemical Assays}

After scintigraphic imaging and ECG recording, all animals were under anesthesia and blood samples $(5 \mathrm{~mL})$ were taken with a syringe by taken from the abdominal aorta. After $30 \mathrm{~min}$, the samples were centrifuged at $3.000 \mathrm{rpm}$ for 10 minutes. Then, the serum was used for all following biochemical assays. Serum blood urea nitrogen (BUN), creatine kinase (CK), cardiac troponin $\mathrm{T}$ ( $\mathrm{cTnT}$ ) were estimated by the kinetic determination with the commercial kits of
Bechman by Bechman Coulter LX-2000 (Brea, CA, USA). Finally, rats were killed by cervical distension.

\section{Statistical Analyses}

Statistical evaluation was performed using the software (SPSSversion15) program and Prism software package (GraphPad, Version 7, USA). All data were presented as means \pm standard error. The Kolmogorov-Smirnov test was used to determine whether the data were normally distributed. The normal dispersed data, one-way analysis of variance (ANOVA) and following Tukey test. The non-normal distribution data, differences among the groups were analyzed by Kruskal Wallis analysis of variance. For all tests, statistical differences with values of $p<0.05$ were considered to be significant.

\section{RESULTS}

\section{Electrocardiography}

The influence of treatment with EDO or ADR on rat ECG parameters is shown in Table 1, additionally, in Figure 2, heartbeat, duration of the 
P wave, QRS complex, QT interval and amplitude of ST segment are presented for all groups.

CON group showed a normal pattern on ECG, whereas in ADR-induced cardiotoxic rats there were statistically an increased in the duration of QT interval ( $p<0.001)$, as well as ST segment prolongation $(\mathrm{p}<0.001)$, and a decreased in heartbeat ( $<<0.001)$, duration of the $P$ wave $(p$ $<0.05)$ and QRS complex ( $<$ < 0.001) compared to the CON group (Figure 2, Table 1).
$\mathrm{ADR}+\mathrm{EDO}$ group did not alter the ECG parameters when compared with the CON group. When the effect of ADR and ADR + EDO was compared, it was shown that QT interval duration ( $\mathrm{p}<0.01)$ and ST segment amplitude was shorter in ADR+ EDO group than ADR groups. Additionally, in ADR + EDO group increased heartbeat $(\mathrm{p}<0.01)$ and duration of the $P$ wave $(p$ $<0.05)$ and QRS Complex duration $(\mathrm{p}<0.001)$ it was significant when compared to the ADRinduced cardiotoxic group (Figure 2, Table 1).

EDO group showed a normal pattern on ECG the same CON groups (Figure 2, Table 1).

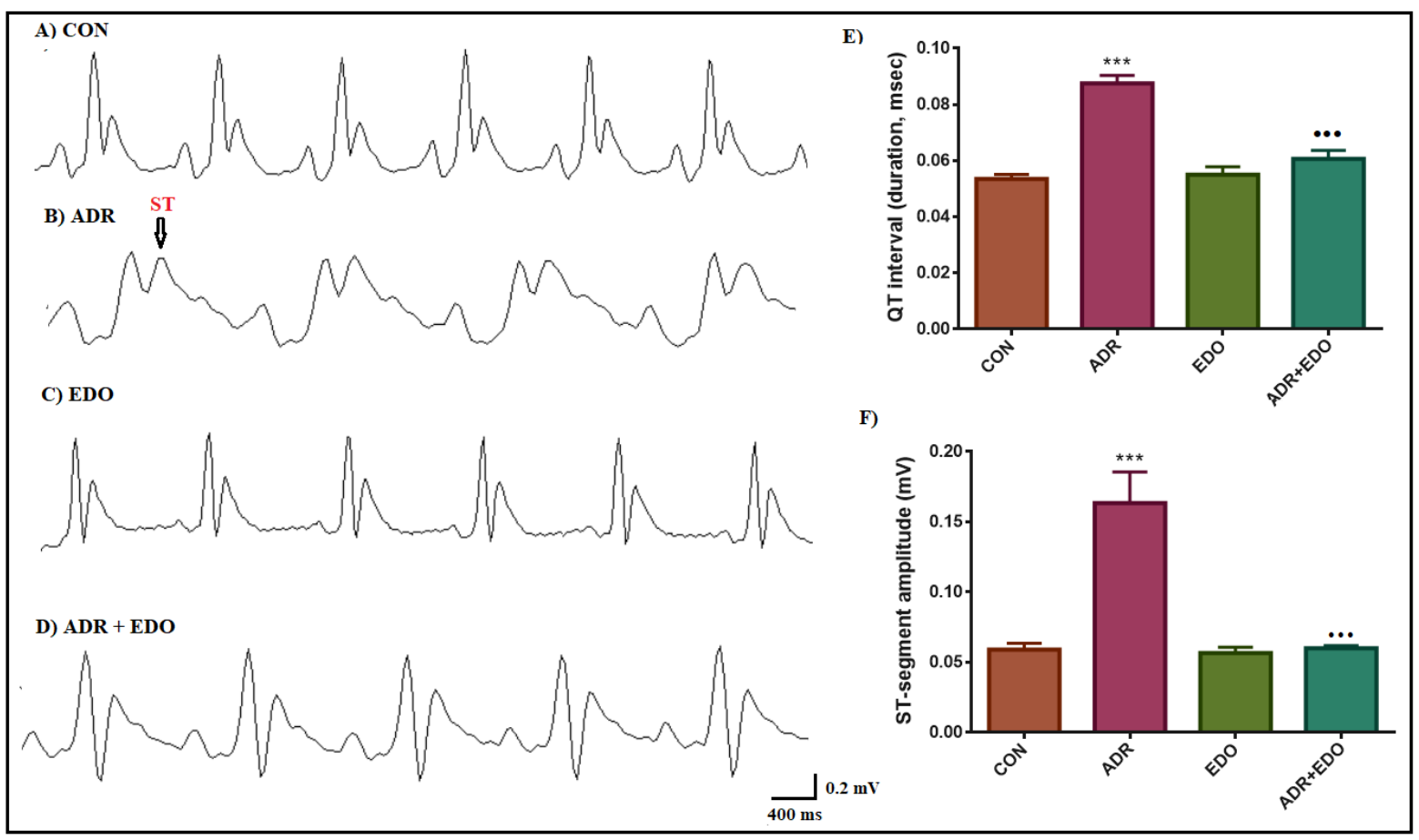

Figure 2. ECG pattern in the A) Control (CON), B) adriamycin (ADR), C) edaravone (EDO), D) adriamycin + edaravone (ADR + EDO) groups, E) duration of QT interval (msec) F) ST-segment amplitude (mV). The ADR groups significantly increased QT interval duration and elevation ST segment amplitude when compared to the CON group $(* * *$ p $<0.001)$. Yet, ADR + EDO did not alter ECG pattern when compared to the CON group. ADR + EDO group significantly reduced the duration of QT interval and level of ST segment amplitude when compared to the ADR group $\left(\bullet^{\bullet \bullet}=\mathrm{p}<0.001\right)$ and similar to the CON group.

Table 1. Electrocardiographic parameters of all 4 groups.

\begin{tabular}{|c|c|c|c|c|c|}
\hline Groups & $\begin{array}{l}\text { Heartbeat } \\
\text { (bpm) }\end{array}$ & $\begin{array}{c}\text { P wave } \\
\text { (duration, s) }\end{array}$ & $\begin{array}{l}\text { QRS Complex } \\
\text { (duration, s) }\end{array}$ & $\begin{array}{l}\text { QT interval } \\
\text { (duration, s) }\end{array}$ & $\begin{array}{c}\text { ST segment } \\
\text { amplitude (mV) }\end{array}$ \\
\hline CON & $286 \pm 5.81$ & $0.025 \pm 0.01$ & $0.060 \pm 0.05$ & $0.053 \pm 0.01$ & $0.059 \pm 0.04$ \\
\hline ADR & $200 \pm 12.7,{ }^{b}$ & $0.017 \pm 0.02,{ }^{a}$ & $0.035 \pm 0.01{ }^{\mathrm{b}}$ & $0.087 \pm 0.02{ }^{b}$ & $0.163 \pm 0.02{ }^{b}$ \\
\hline EDO & $284 \pm 5.81$ & $0.025 \pm 0.02$ & $0.064 \pm 0.03$ & $0.055 \pm 0.02$ & $0.056 \pm 0.04$ \\
\hline ADR + EDO & $268 \pm 17.4,{ }^{\mathrm{d}}$ & $0.024 \pm 0.01{ }^{\mathrm{c}}$ & $0.057 \pm 0.02{ }^{\mathrm{e}}$ & $0.060 \pm 0.03{ }^{\mathrm{e}}$ & $0.059 \pm 0.02{ }^{\mathrm{e}}$ \\
\hline
\end{tabular}

Electrocardiographic parameters of control (CON), adriamycin (ADR), edaravone (EDO), adriamycin + edaravone $(\mathrm{ADR}+\mathrm{EDO})$ groups. Data are presented as mean \pm SEM. $\left({ }^{\mathrm{a}}=\mathrm{p}<0.05,{ }^{\mathrm{b}}=\mathrm{p}<0.001\right)$ all groups compared to the CON group; $\left({ }^{\mathrm{c}}=\mathrm{p}<0.05,{ }^{\mathrm{d}}=\mathrm{p}<0.01, \stackrel{\mathrm{e}}{=} \mathrm{p}<0.001\right)$ ADR+ EDO group compared to the ADR group. 


\section{Biochemical Assays}

As shown in Table 2 and figure 3, ADR injection significantly increased plasma blood urea nitrogen (BUN) level by (797\%, p< 0.001) plasma creatine kinase $(\mathrm{CK})$ level by $(822 \%, \mathrm{p}<0.001)$ and cardiac troponin $\mathrm{T}$ (cTnT) levels by $(502 \%$, $\mathrm{p}<0.001)$ compared to the CON group. EDO alone did not change BUN, CK, cTnT $(110,97 \%$ and $97 \%$, respectively) when compared to the CON group (Table 2 and figure 3 ).
ADR + EDO groups, in other words, pretreatment of ADR-induced toxic rat with EDO, increased BUN by (368\%, p< 0.05), CK levels by ( $262 \%$, $\mathrm{p}<0.05)$ and $\mathrm{cTnT}$ by $(215 \%, \mathrm{p}<0.05)$ when compared to CON group. However, ADR + EDO group significantly decreased BUN, CK and cTnT level by (46\%; 31\%; 42\%, p< 0.001, respectively) when compared to the ADR toxic group (Table 2 and figure 3 ).

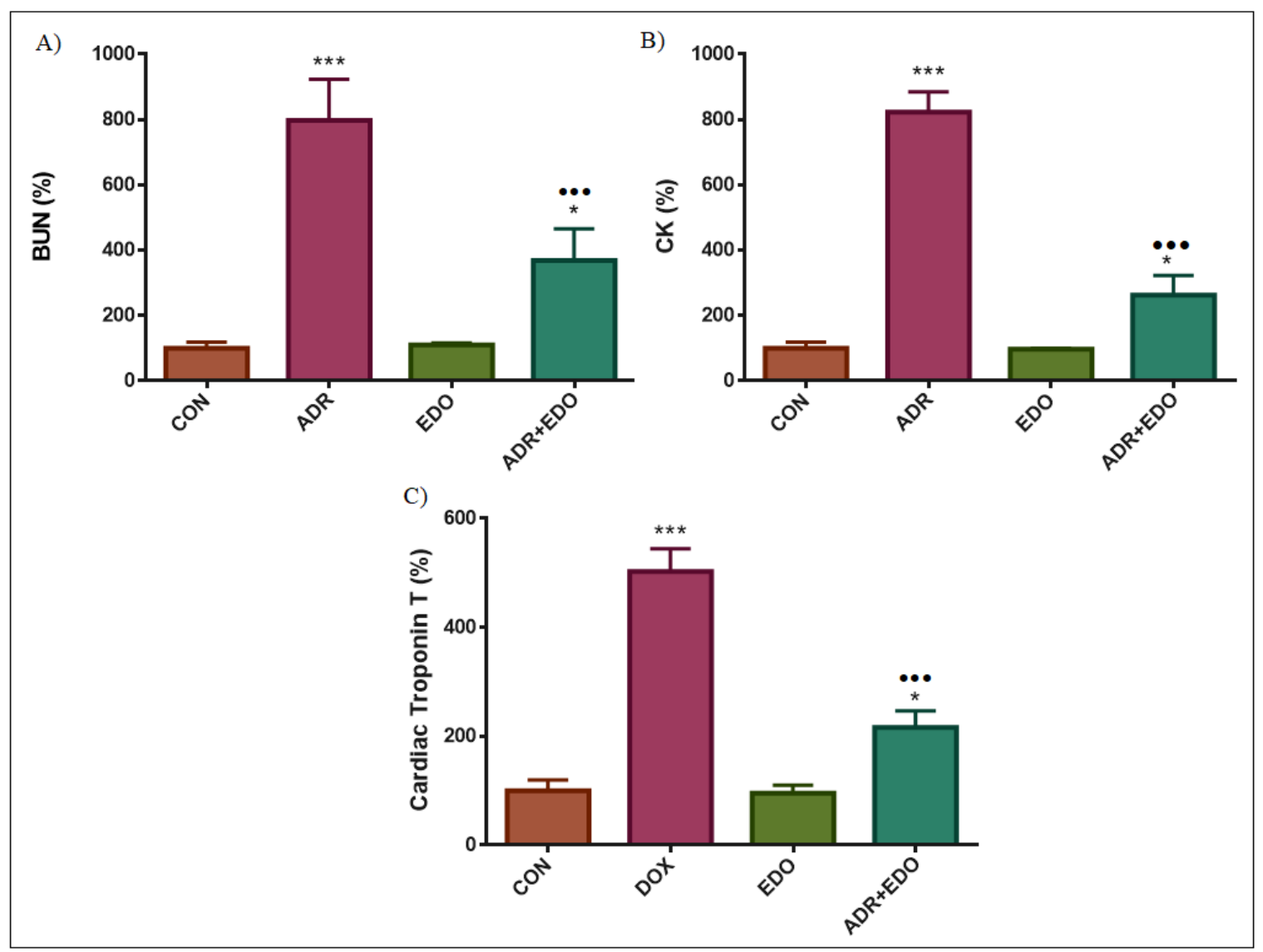

Figure 3. The effect of control (CON), adriamycin (ADR), edaravone (EDO), adriamycin + edaravone (ADR + EDO) groups on the effect of BUN (A), CK (B) and cTnT (C). Data are presented as mean \pm SEM. The ADR group significantly increased BUN, CK and cTnT compared to the CON group $\left(\left({ }^{*} \mathrm{p}<0.05, * * * \mathrm{p}<0.001\right)\right.$. ADR + EDO group significantly decreased BUN, CK and cTnT level compared to the ADR group $\left(\bullet^{\bullet \bullet}=\mathrm{p}<0.001\right)$.

Table 2. The biochemical data parameter of all groups.

\begin{tabular}{lccc}
\hline Groups & BUN & CK & cTnT \\
\hline CON & $17.50 \pm 3.2$ & $0.41 \pm 0.07$ & $1650 \pm 323$ \\
ADR & $139.5 \pm 22.1,{ }^{\mathrm{b}}$ & $3.37 \pm 0.25,{ }^{\mathrm{b}}$ & $8288 \pm 683,{ }^{\mathrm{b}}$ \\
EDO & $19.30 \pm 0.9$ & $0.39 \pm 0.02$ & $1576 \pm 244$ \\
ADR + EDO & $64.55 \pm 16.8,{ }^{\mathrm{a}, \mathrm{c}}$ & $1.07 \pm 0.24,{ }^{\mathrm{a}, \mathrm{c}}$ & $3560 \pm 513,{ }^{\mathrm{a}, \mathrm{c}}$ \\
\hline
\end{tabular}

Summarizes the statistical analysis of the BUN, CK and cTnT levels in plasma all groups. control (CON), adriamycin $(\mathrm{ADR})$, edaravone (EDO), adriamycin + edaravone $(\mathrm{ADR}+\mathrm{EDO})$ groups. Data are presented as mean $\pm \mathrm{SEM} .\left({ }^{\mathrm{a}}=\mathrm{p}<\right.$ $\left.0.05,{ }^{\mathrm{b}}=\mathrm{p}<0.001\right)$ all groups compared to the CON group; $\left({ }^{\mathrm{c}}=\mathrm{p}<0.001\right)$ ADR + EDO group compared to the ADR group. 


\section{Scintigraphic Images}

As shown in Table 3 and Figure 4, ADR injection significantly increased ${ }^{99 \mathrm{~m}} \mathrm{Tc}-\mathrm{PYP}$ uptake level in the heart by $550 \%(\mathrm{p}<0.001)$ when compared to the CON group. As substance control, EDO alone did not change ${ }^{99 \mathrm{~m}} \mathrm{Tc}-\mathrm{PYP}$ uptake level in the heart by $104 \%$ compared to the CON group (Table 3 and Figure 4). ADR + EDO groups, in other words, pretreatment of an ADR-induced toxic rat with EDO, increased ${ }^{99 \mathrm{~m}} \mathrm{Tc}-\mathrm{PYP}$ uptake level in the heart by $281 \%$ ( $p<0.01)$, when compared to the CON group. However, ADR + EDO group significantly decreased ${ }^{99 \mathrm{~m}} \mathrm{Tc}-\mathrm{PYP}$ uptake level in the heart by $51 \%(\mathrm{p}<0.001)$ when compared to the ADR-toxic group (Table 3 and Figure 4).

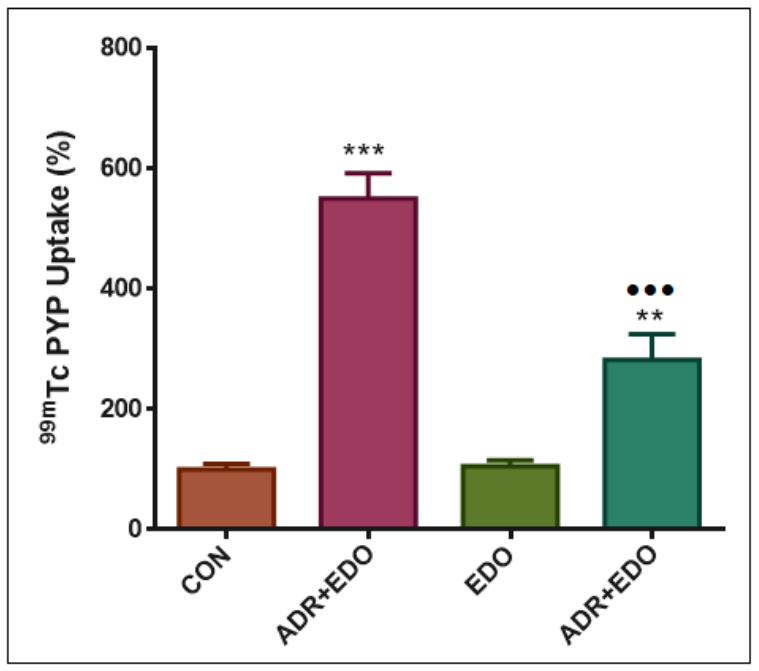

Figure 4. Control (CON), adriamycin (ADR), edaravone (EDO), adriamycin + edaravone (ADR + EDO) groups on the effect of ${ }^{99 \mathrm{~m}} \mathrm{Tc}$-PYP uptake level of the heart. Data are presented as mean \pm SEM. The ADR group significantly increased ${ }^{99 \mathrm{~m}} \mathrm{Tc}-\mathrm{PYP}$ uptake when compared to the CON group (***p<0.001). ADR + EDO group increased ${ }^{99 m}$ Tc-PYP uptake level in hearth when compared to the CON group $(* * p<0.01)$. ADR + EDO significantly decreased ${ }^{99 m}$ Tc-PYP uptake level when compared to the ADR group ( ${ }^{\bullet \bullet \bullet}=$ $\mathrm{p}<0.001)$.
Table 3. The scintigraphic data parameter of all groups.

\begin{tabular}{lc}
\hline Groups & $\begin{array}{c}{ }^{99 m} \text { Tc-PYP } \\
\text { Uptake }\end{array}$ \\
\hline CON & $50937 \pm 463$ \\
AMT & $280307 \pm 214$ \\
EDO & $53480 \pm 517$ \\
AMT + EDO & $143570 \pm 217$ \\
\hline
\end{tabular}

Summarizes the statistical analysis of the ${ }^{99 \mathrm{~m}} \mathrm{Tc}$ PYP Uptake levels of control (CON), adriamycin (ADR), edaravone (EDO), adriamycin + edaravone (ADR + EDO $)$ groups. Data are presented as mean \pm SEM. $\left({ }^{\mathrm{a}}=\mathrm{p}\right.$ $\left.<0.01,{ }^{b}=\mathrm{p}<0.001\right)$ all groups compared to the CON group; $\left({ }^{c}=\mathrm{p}<0.001\right)$ ADR + EDO group compared to the ADR group. 


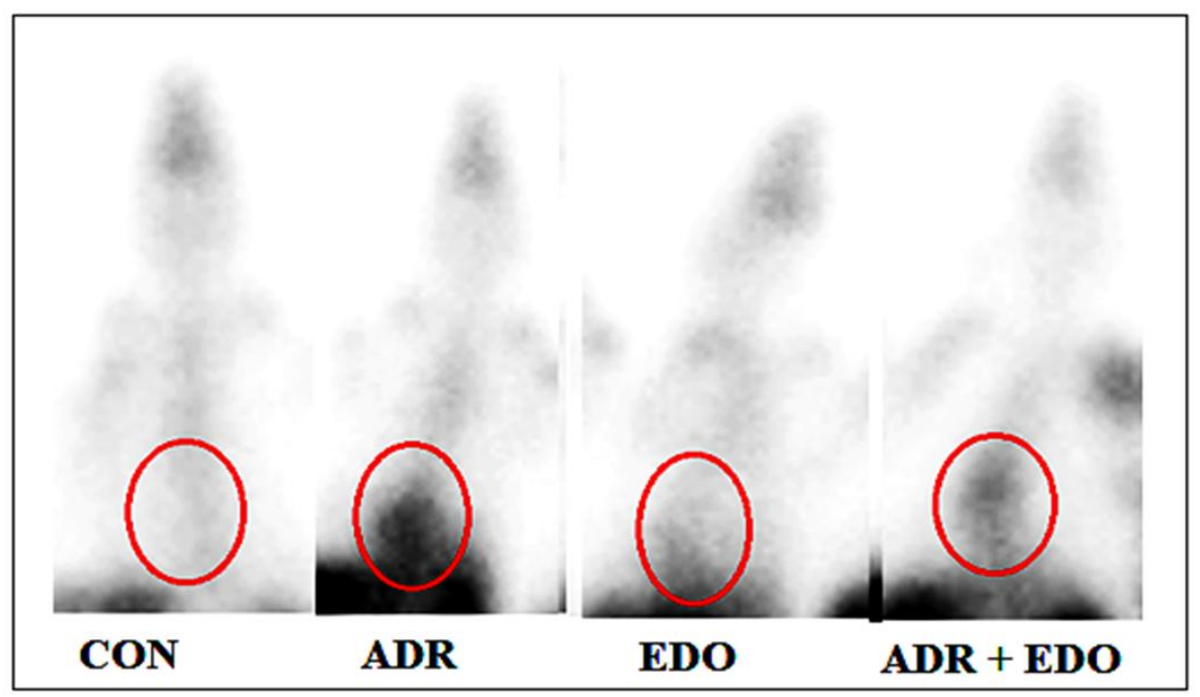

Figure 5. Static images in posterior position of all groups; control (CON), adriamycin (ADR), edaravone (EDO), adriamycin + edaravone (ADR + EDO) groups. The ${ }^{99 \mathrm{~m}} \mathrm{Tc}-\mathrm{PYP}$ uptake was calculated for each rat by drawing equal rectangular ROI at the heart area. It was observed that ${ }^{99 \mathrm{~m}} \mathrm{Tc}-\mathrm{PYP}$ uptake in the heart was higher in the ADR group. On the other hand, in the ADR group, ${ }^{99 \mathrm{~m}} \mathrm{Tc}-\mathrm{PYP}$ uptake appeared to be higher because of the developing damage. ADR + EDO groups significantly decreased ${ }^{99 \mathrm{~m}} \mathrm{Tc}-\mathrm{PYP}$ uptake level when compared to the CON group.

\section{DISCUSSION}

In this study, we aimed to investigate the cardioprotective effect of EDO treatments in ADR-induced cardiotoxic rats using electrocardiography (ECG), ${ }^{99 \mathrm{~m}} \mathrm{Tc}-\mathrm{PYP}$ uptake hearth scintigraphic imaging techniques and biochemical parameters including BUN, CK, and cTnT. We showed that ADR application led to heart damage and ${ }^{99 \mathrm{~m}}$ Tc-PYP uptake had strong correlations with, electrocardiographic and biochemical results. Pretreatment with EDO reduced ADR-induced abnormalities.

ECG is one of the standard methods used to assess cardiac function and its abnormalities are generally showed for the diagnosis of myocardial damage. This study showed that ADR application caused conduction abnormalities on ECG by decreased heartbeat, $\mathrm{P}$ wave and QRS complex duration and increased both ST-segment amplitude and QT interval duration. Similarly, a lot of studies also show these ECG abnormalities on the cardiotoxicity of ADR. Previous studies showed that ADR treatment induced ECG abnormalities, which consist of sinus tachycardia, changes of the $\mathrm{P}$ wave, QRS complex and $\mathrm{R}$ amplitude are frequently transient and cannot be said to be specific to ADR-induced cardiotoxicity $^{13-15}$.

However, elevation ST segment amplitude and prolongation QT interval duration and have been reported to be relatively characteristic ECG findings in ADR-induced cardiotoxicity, as well as in this study,14-16. It is suggested that prolongation QT interval and elevation of the ST segment amplitude occurs by loss of cellular membrane due to reactive oxygen species (ROS) and oxidative stress ${ }^{4}$. A lot of studies demonstrated that ROS and oxidative stress apparently play a key role in ADR-induced cardiotoxicity ${ }^{17,18}$. EDO is a potent antioxidant and a free radical scavenger ${ }^{19}$. A study showed that pretreatment with EDA effectively reduced ADR-associated conduction abnormalities, as well as in this study ${ }^{19}$. In this study, pretreatment with EDO caused increased in heartbeat, duration of $\mathrm{P}$ wave and QRS complex, reduced QT interval duration and elevation of ST segment amplitude was also near to normal. These changes in the electrocardiogram pattern induced by EDO may be due to its membrane stabilizing action.

Previous studies demonstrated that cardiac injury induced by ADR may be due to the increases of lipid peroxidation, DNA fragmentation, protein cross-linking, and resulting from oxidative stress $^{20,21}$. Increased oxidative stress destruct myocardial cells, causing rupture of the cell membrane. As a result of this, BUN, CK and cTnT were released into the bloodstream. Also, increased levels of these biochemical markers in plasma are an indicator of the severity of ADRinduced myocardial injury ${ }^{22}$. 
Many previous studies demonstrated that a cumulative dose of ADR caused an elevation in the levels of BUN, CK and cTnT serum biomarker. We also demonstrated that ADR application increased plasma BUN, CK and cTnT levels in plasma. Pretreatment with EDO importantly reduced of this biochemical marker. An animal study demonstrated that EDO injection reduced cardiac biomarkers in isoproterenolinduced myocardial infarction ${ }^{23}$. A lot of studies demonstrated that EDO has anti-necrotic, antiapoptotic, anti-inflammatory cytokine effects on cardiovascular diseases ${ }^{23-25}$. EDO restricts the leakage of these biochemical markers, which can be accounted for by $\mathrm{Ca}^{+2}$ channel blockage effect and membrane-stabilizing property ${ }^{23}$.

${ }^{99 \mathrm{~m}}$ Tc-PYP scintigraphic imaging shows necrotic tissues and used detection of myocardial injury and metabolic diseases or tumors ${ }^{26,27}$. This is based on abnormal intracellular uptake of calcium from damaged cells $^{28}$. Therefore, it has been considered beneficial in the diagnosis of acute phase myocardial infarction and quantification of the infarct size in the clinical setting ${ }^{26,29}$. Previous studies have also suggested that ${ }^{99 \mathrm{~m}} \mathrm{Tc}-\mathrm{PYP}$ is a good index of the severity of tissue injury ${ }^{8,30,31}$. In the present study, we demonstrated an increased ${ }^{99 \mathrm{~m}}$ Tc-PYP uptake on the heart area in the ADR induced cardiotoxic rats. Treatment with EDO displayed a significant decrease in the levels of ${ }^{99 \mathrm{~m}} \mathrm{Tc}$ PYP on the heart area.

\section{CONCLUSION}

The results of the in this study revealed that pretreatment with EDO showed a considerable cardioprotective effect on ADR-induced cardiotoxicity in the rat model. As a result of the study, it was thought that ${ }^{99 \mathrm{~m}} \mathrm{Tc}-\mathrm{PYP}$ scintigraphy imaging could be used in the follow-up of using antineoplastic drug including ADR. In addition these data, as for the cardiotoxicity induced by ADR, ECG results are very variable and biochemical markers are alone not sufficient; thus, additional diagnostic methods are also needed.

\section{REFERENCES}

1. Damiani RM, Moura DJ, Viau CM, et al. Pathways of cardiac toxicity: comparison between chemotherapeutic drugs doxorubicin and mitoxantrone. Arch Toxicol. 2016;90:2063-2076.

2. Wang L, Zhang X, Chan JY, et al. A novel danshensu derivative prevents cardiac dysfunction and improves the chemotherapeutic efficacy of doxorubicin in breast cancer cells. J Cell Biochem. 2016;117:94-105.

3. Castells MC, Tennant NM, Sloane DE, et al. Hypersensitivity reactions to chemotherapy: outcomes and safety of rapid desensitization in 413 cases, J Allergy Clin Immunol. 2008;122(3):574-580.

4. Cappetta D, Rossi F, Piegari E, et al. Doxorubicin targets multiple players: a new view of an old problem. Pharmacol Res. 2018;127:4-14.

5. Anjos Ferreira AL, Russell RM, Rocha N, et al. Effect of lycopene on doxorubicininduced cardiotoxicity: an echocardiographic, histological and morphometrical assessment. Basic Clin Pharmacol Toxicol. 2007;101:16-24.

6. Swamy AH, Wangikar U, Koti BC, et al. Cardioprotective effect of ascorbic acid on doxorubicin-induced myocardial toxicity in rats. Indian J Pharmacol. 2011;43(5):507511.

7. Aygun $\mathrm{H}, \mathrm{Gul}$ SS. Effects of melatonin and agomelatine on doxorubicin induced anxiety and depression-like behaviors in rats. Medical Science and Discovery. 2018;5(7):253-259.

8. Gül SS, Aygün H. Cardioprotective effect of vitamin $\mathrm{D}$ and melatonin on doxorubicin-induced cardiotoxicity in rat model: an electrocardiographic, scintigraphic and biochemical study. The European Res J. 2018. doi: 10.18621/eurj.410029.

9. Aygun H, Gul SS. Protective effect of melatonin and agomelatine on adriamycininduced nephrotoxicity in rat model: a renal scintigraphy and biochemical study. Bratisl Med J. 2019;120(2):119-123.

10. The Edaravone Acute Infarction Study Group. Effect of a novel free radical scavenger, edaravone (MCI-186), on acute brain infarction. Randomized, placebocontrolled, double-blind study at multicenters. Cerebrovasc Dis. 2003;15:222-229.

11. Tokumaru O, Shuto Y, Ogata K, et al. Dose-dependency of multiple free radicalscavenging activity of edaravone. J Surg Res. 2018;228:147-153.

12. Abe S, Kirima K, Tsuchiya K, et al. The reaction rate of edaravone (3-methyl-1phenyl-2-pyrazolin5-one (MCI-186)) with 
hydroxyl radical. Chem Pharm Bull. (Tokyo) 2004;52(2):186-191.

13. Suzuki J, Yanagisawa A, Shigeyama T, et al. Early detection of anthracycline-induced cardiotoxicity by radionuclide angiocardiography. Angiology 1999;50:3745.

14. Koti BC, Nagathan S, Vishwanathswamy A, et al. Cardioprotective effect of Vedic Guard against doxorubicin-induced cardiotoxicity in rats: A biochemical, electrocardiographic, and histopathological study. Pharmacogn Mag. 2013;9:176-181.

15. Bhatt L, Joshi V. Mangifera indica L. leaf extract alleviates doxorubicin induced cardiac stress. J Intercult Ethnopharmacol. 2017;6:284-289.

16. Bilginoglu A, Aydın D, Ozsoy S, Aygün H. Protective effect of melatonin on adriamycin-induced cardiotoxicity in rats. Turk Kardiyol Dern Ars 2014;42(3):265273.

17. Zhang S, Liu X, Bawa-Khalfe $\mathrm{T}$, et al. Identification of the molecular basis of doxorubicin-induced cardiotoxicity. Nat Med. 2012;18:1639-1642.

18. Renu K, Abilash VG, P B TP, et al. Molecular mechanism of doxorubicininduced cardiomyopathy-An update. Eur J Pharmacol. 2018;818:241-253.

19. Xin $\mathrm{Y}$, Zhan $\mathrm{S}, \mathrm{Gu} \mathrm{L}$, et al. Electrocardiographic and biochemical evidence for the cardioprotective effect of antioxidants in acute doxorubicin-induced cardiotoxicity in the beagle dogs. Biol Pharm Bull. 2011;34(10):1523-1526.

20. Wang S, Konorev EA, Kotamraju S, et al. Doxorubicin induces apoptosis in normal and tumor cells via distinctly different mechanisms. intermediacy of $\mathrm{H}(2) \mathrm{O}(2)-$ and p53-dependent pathways. J Biol Chem. 2004;279:25535-25543.

21. Peng X, Chen B, Lim CC, Sawyer DB. The cardiotoxicology of anthracycline chemotherapeutics: translating molecular mechanism into preventative medicine. Mol Interv. 2005;5(3):163-171.

22. Wakade AS, Shah AS, Kulkarni MP, Juvekar AR. Protective effect of Piper longum L. on oxidative stress induced injury and cellular abnormality in adriamycin induced cardiotoxicity in rats. Indian J Exp Biol. 2008;46:528-533.

23. Hassan MQ, Akhtar MS, Akhtar M, et al. Edaravone, a potent free radical scavenger and a calcium channel blocker attenuate isoproterenol induced myocardial infarction by suppressing oxidative stress, apoptotic signaling and ultrastructural damage. Ther Adv Cardiovasc Dis. 2016;10(4):214-223.

24. Kikuchi K, Tancharoen S, Takeshige N, et al. The efficacy of edaravone (radicut), a free radical scavenger, for cardiovascular disease. Int J Mol Sci. 2013;14(7):1390913930.

25. Im GJ, Chang J, Lee $S$, et al. Protective role of edaravone against cisplatin-induced ototoxicity in an auditory cell line. Hear Res. 2015;330:113-118.

26. Mochizuki T, Murase K, Higashino H, et al. Ischemic "memory image" in acute myocardial infarction of 123I-BMIPP after reperfusion therapy: a comparison with $99 \mathrm{mTc}$-pyrophosphate and $201 \mathrm{Tl}$ dualisotope SPECT. Ann Nucl Med. 2002;16(8):563-568.

27. Einstein AJ, Shuryak I, Castano A, et al. Estimating cancer risk from $99 \mathrm{mTc}$ pyrophosphate imaging for transthyretin cardiac amyloidosis. J Nucl Cardiol. 2018. doi: 10.1007/s12350-018-1307-7.

28. Isoda $\mathrm{H}$, Itagaki $\mathrm{Y}$, Nomura $\mathrm{N}$, et al. Usefulness of dual SPECT with Tc-99m pyrophosphate and Tl-201 to predict further events after acute myocardial infarction with single-vessel coronary artery disease. Clin Nucl Med. 1999;24(4):227-231.

29. Okuda K, Nohara R, Fujita M, et al. Technetium-99m-pyrophosphate uptake as an indicator of myocardial injury without infarct. J Nucl Med 1994;35:1366-1370.

30. Affleck DG, Edelman L, Morris SE, Saffle JR. Assessment of tissue viability in complex extremity injuries: utility of the pyrophosphate nuclear scan. J Trauma. 2001;50:263-269.

31. Chang HR, Kao CH, Lian JD, et al. Evaluation of the severity of traumatic rhabdomyolysis using technetium-99m pyrophosphate scintigraphy. Am J Nephrol. 2001;21:208-214. 